\title{
First comparison of French and Australian OsHV-1 pvars by bath exposure
}

\author{
Colleen A. Burge ${ }^{1, *}$, Kimberly S. Reece ${ }^{2, *}$, Arun K. Dhar ${ }^{3}$, Peter Kirkland ${ }^{4}$, \\ Benjamin Morga $^{5}$, Lionel Dégremont ${ }^{5}$, Nicole Faury ${ }^{5}$, Bryanda J. T. Wippel ${ }^{6}$, \\ Alanna MacIntyre ${ }^{2}$, Carolyn S. Friedman ${ }^{6}$
}

\author{
${ }^{1}$ Institute of Marine and Environmental Technology, University of Maryland Baltimore County, 701 E Pratt Street, Baltimore \\ Maryland 21202, USA \\ ${ }^{2}$ Virginia Institute of Marine Sciences, William \& Mary, PO Box 1346, Gloucester Point, Virginia 23062, USA \\ ${ }^{3}$ Aquaculture Pathology Laboratory, School of Animal and Comparative Biomedical Sciences, The University of Arizona, \\ 1117 E Lowell Road, Tucson, AZ 85721, USA \\ ${ }^{4}$ Elizabeth Macarthur Agricultural Institute, NSW Department of Primary Industries, Menangle, NSW 2568, Australia \\ ${ }^{5}$ Ifremer, RBE-SG2M-LGPMM, Station La Tremblade, 17390 La Tremblade, France \\ ${ }^{6}$ School of Aquatic and Fishery Sciences, University of Washington, Box 355020, Seattle, WA 98195, USA
}

\begin{abstract}
Economically devastating mortality events of farmed and wild shellfish due to infectious disease have been reported globally. Currently, one of the most significant disease threats to Pacific oyster Crassostrea gigas culture is the ostreid herpesvirus 1 (OsHV-1), in particular the emerging OsHV-1 microvariant genotypes. OsHV-1 microvariants (OsHV-1 $\mu v a r s)$ are spreading globally, and concern is high among growers in areas unaffected by OsHV-1. No study to date has compared the relative virulence among variants. We provide the first challenge study comparing survival of naïve juvenile Pacific oysters exposed to OsHV-1 $\mu$ vars from Australia (AUS $\mu v a r$ ) and France (FRA $\mu$ var). Oysters challenged with OsHV-1 $\mu v a r s$ had low survival $(2.5 \%$ exposed to AUS uvar and $10 \%$ to FRA uvar), and high viral copy number as compared to control oysters (100\% survival and no virus detected). As our study was conducted in a quarantine facility located $\sim 320 \mathrm{~km}$ from the ocean, we also compared the virulence of OsHV-1 $\mu$ vars using artificial seawater made from either facility tap water $\left(3782 \mu \mathrm{mol} \mathrm{kg}{ }^{-1}\right.$ seawater total alkalinity) or purchased distilled water $\left(2003 \mu \mathrm{mol} \mathrm{kg}{ }^{-1}\right)$. Although no differences in survival or viral copy number were detected in oysters exposed to seawater made using tap or distilled water, more OsHV-1 was detected in tanks containing the lower-alkalinity seawater, indicating that water quality may be important for virus transmission, as it may influence the duration of viral viability outside of the host.
\end{abstract}

KEY WORDS: Ostreid herpesvirus 1 - Microvariant - OsHV-1 $\mu$ vars · POMS - Pacific oyster · Crassostrea gigas $\cdot$ Viral disease $\cdot \mathrm{qPCR} \cdot$ Alkalinity $\cdot$ Emerging infectious diseases

\section{INTRODUCTION}

A robust aquaculture industry is dependent on understanding risks, such as disease, that affect production. Cultured oysters contribute billions of dollars to the global economy, with the key species cul-

\footnotetext{
*Corresponding authors: colleenb@umbc.edu
}

tured, the Pacific oyster Crassostrea gigas, alone generating over 1 billion USD in 2016 (FAO 2018). Over the past several decades, devastating losses in farmed and wild shellfish due to infectious diseases have been reported (reviewed by Carnegie et al. 2016). Of the current diseases impacting Pacific oys-

(C) The authors 2020. Open Access under Creative Commons by Attribution Licence. Use, distribution and reproduction are unrestricted. Authors and original publication must be credited. 
ter aquaculture, the ostreid herpesvirus 1 (OsHV-1) and its variants are considered one of the most significant threats to culture of this species globally (Barbosa-Solomieu et al. 2015). OsHV-1 is a doublestranded DNA virus (207 kb; $116 \mathrm{~nm}$ in size) in the order Herpesvirales (Davison et al. 2005, 2009).

OsHV-1 and its variants, particularly the OsHV-1

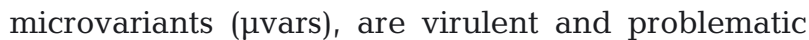
viruses of larval, seed, and adult Pacific oysters (reviewed by Barbosa-Solomieu et al. 2015, Pernet et al. 2016, Burge et al. 2018). In the 1990s, losses of larval and juvenile oysters associated with OsHV-1 were first described in France, New Zealand, and the USA (reviewed by Burge et al. 2018). One variant, known as the OsHV-1 reference strain, was purified, described, and fully sequenced from infected oyster larvae in France (Davison et al. 2005). Since 2008, an economically devastating increase in C. gigas mortality has been associated with new genetic variants of

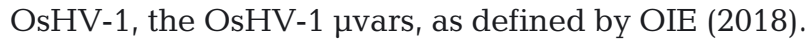
OsHV-1 $\mu v a r s$ have spread within Europe and have caused losses in Australia, New Zealand, and Asia (reviewed by Pernet et al. 2016, Burge et al. 2018). Sequence variations in some genomic regions have been observed among the different OsHV-1 $\mu$ vars (BarbosaSolomieu et al. 2015, Abbadi et al. 2018), although a complete understanding of strain variation and how this impacts virus phenotype remains unknown.

Given the emergence and spread of the OsHV-1 $\mu v a r s$ over the past decade, it may be only a matter of time before currently uninfected Pacific oyster culture areas such as the US West Coast are impacted. Laboratory-based transmission studies in quarantine make it possible to test the susceptibility of Pacific oysters to OsHV-1 pvars (Schikorski et al. 2011 a,b, Kirkland et al. 2015). However, no study to date has compared the susceptibility of Pacific oysters to more than 1 OsHV-1 variant. In this study, OsHV-1 $\mu v a r s$

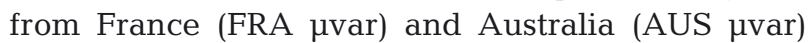
were used to challenge naïve juvenile Pacific oysters. Using a laboratory infection model (Kirkland et al. 2015) in quarantine, our primary objective was to compare these 2 viral variants with respect to host survivorship and infection using viral load (determined by quantitative PCR, qPCR), as a proxy of infection. Our research was conducted in a quarantine facility $\sim 320 \mathrm{~km}$ from the ocean, requiring us to make artificial seawater (ASW) for these studies. Therefore, our secondary objective was to compare survivorship, infection, and virus copy numbers available in tank water using seawater made from either well water that was available at the facility or purchased distilled water.

\section{MATERIALS AND METHODS}

\subsection{Oysters and holding}

Diploid Pacific oysters ( 9 mm), which had never been selected for resistance to OsHV-1 infection, were produced by a supplier in Kona, Hawaii (from a mixed pod of Molluscan Broodstock Program broodstock held in Bay Center, Washington) and grown at a floating upwelling system ('flupsy,' a nursery system) in Humboldt Bay, California, prior to shipment (on ice) to the University of Arizona, Aquaculture Pathology Laboratory (UA APL) in Tucson, Arizona. On arrival, oysters were brought up to $\sim 18^{\circ} \mathrm{C}$ at 30-31 ppt and held for $2 \mathrm{~d}$ prior to the beginning of the experiment. All ASW was made with Crystal Sea ${ }^{\circledR}$ MarineMix 150 gallon ( 567 l) mixture (Marine Enterprises International) dissolved in well water available at the UA APL (ASW Tap ).

\subsection{OsHV-1 homogenate prep}

Stocks of inoculum of the AUS $\mu$ var (a derivative of the Australian prototype strain; Kirkland et al. 2015) and FRA $\mu$ var (tissue prepared from infected oysters collected in Marennes-Oléron Bay following protocols of Schikorski et al. 2011a,b) were shipped directly to the UA APL with permission from the USDA-APHIS and the Arizona state veterinarian. In order to conduct multiple experimental challenges with the same inoculum, we produced a larger stock of $0.22 \mu \mathrm{m}$ filtered homogenate that was cryopreserved using $10 \%$ fetal bovine serum $/ 10 \%$ glycerol and stored at $-80^{\circ} \mathrm{C}$ at the UA APL (Kirkland et al. 2015). Briefly, $0.22 \mu \mathrm{m}$ filtered homogenate was produced by injecting susceptible naïve sub-adult Pacific oysters $(\mathrm{n}=10)$. At $48 \mathrm{~h}$ post-injection, gill and mantle were excised, homogenized, and filtered $(0.22 \mu \mathrm{m})$ to create inocula (Burge \& Friedman 2012, Kirkland et al. 2015). Viral copy numbers were quantified by extracting $200 \mu \mathrm{l}$ of each inoculum using a Zymo Quick DNA Mini-Plus Kit and the Biological Fluids and Cells method, followed by OsHV-1 specific qPCR (see Section 2.4).

For each inoculum, a genetic characterization was made by amplifying DNA from 2 regions of the OsHV-1 genome, the ' $\mathrm{C}$ ' and 'IA' regions, using the $\mathrm{C} 2 / \mathrm{C} 6$ primers (targeting open reading frame [ORF] 4) and IA1/IA2 primers (targeting ORF 43), respectively (Renault \& Arzul 2001). Each inoculum was run in duplicate with 2 negative control reactions. Briefly, $50 \mathrm{pl}$ reactions contained $1 \times$ PCR buffer, $0.2 \mathrm{mM}$ 
each dNTP, $1.5 \mathrm{mM} \mathrm{MgCl} 2,0.3 \mu \mathrm{m}$ of each primer, 2.5 U DNA polymerase (Promega GoTaq 9PIM300), and $4 \mathrm{\mu l}$ of DNA using PCR cycling conditions described by Segarra et al. (2010) and OIE (2018). Following PCR amplification, PCR products were run on a standard agarose gel (Segarra et al. 2010) to ensure 1 band at the appropriate size was obtained before submitting to the IMET Bioanalytical Services lab (Baltimore, MD) for direct sequencing. Briefly, 10 $\mu l$ of each PCR reaction were cleaned (Ampure, Beckman Coulter) and sequenced bi-directionally using the BigDye Terminator v3.1 Cycle Sequencing kit (Thermo Fisher Scientific) and run on the 3130 XL Genetic Analyzer from Life Technologies. Sequence base pairs were called using Sequencher (Gene Codes), and alignments of the AUS pvar and FRA $\mu v a r$ were created using Clustal Omega (EMBL-EBI).

\subsection{Experimental challenges}

Challenges were conducted in 31 tanks with aeration at $21-22^{\circ} \mathrm{C}$ with 10 oysters $(\sim 9 \mathrm{~mm})$ per tank. For each OsHV-1 $\mu v a r, 2$ tanks contained artificial seawater made using well water $\left(\mathrm{ASW}_{\text {Tap }}\right)$ and 2 tanks contained ASW made with distilled water ( $\left.\mathrm{ASW}_{\text {Dist }}\right)$. Similarly, control tanks contained either $\operatorname{ASW}_{\text {Tap }}(\mathrm{n}=2)$ or $\mathrm{ASW}_{\text {Dist }}(\mathrm{n}=2)$. The alkalinity of $\mathrm{ASW}_{\text {Tap }}$ and $\mathrm{ASW}_{\text {Dist }}$ was assayed using end-point titration according to the methods of Wippel (2017).

Prior to addition to the challenge experiment, oysters were brought up to $22^{\circ} \mathrm{C}$ and relaxed using $\mathrm{MgCl}_{2}$ (50 g $\mathrm{l}^{-1}$ in $3 \mathrm{l}$ for $\sim 100$ oysters) to ensure comparative exposure of each virus for $2 \mathrm{~h}$ before 10 animals were added to each tank containing $2.5 \mathrm{l}$ of the appropriate seawater. Aliquots $(500 \mathrm{ml})$ of $1.00 \times 10^{7}$ virus copies $\mathrm{ml}^{-1}$ homogenate were added to each tank to obtain a final concentration of $1.67 \times 10^{6}$ virus copies $\mathrm{ml}^{-1}$. Each day, oysters were monitored for mortality by lightly tapping the tank and watching for oyster valve closure; dead animals and $1 \mathrm{ml}$ of seawater from each tank were collected on each day of the experiment and frozen at $-80^{\circ} \mathrm{C}$ for future qPCR analysis. Tank water was changed every $48 \mathrm{~h}$. After $6 \mathrm{~d}$, all survivors were collected and frozen at $-80^{\circ} \mathrm{C}$.

\subsection{OsHV-1 quantification in oysters and seawater}

OsHV-1 specific qPCR was used to determine the viral load in all oysters and from seawater collected from each tank on each day of the experiment. Sam- ples were processed in a BSL3 facility. The Zymo Quick-DNA Mini Plus kit was used following the manufacturer's protocol to extract $200 \mu \mathrm{l}$ of tank water (Biological Fluids and Cells method) or $\sim 25 \mathrm{mg}$ of gill and mantle tissue (Solid Tissues method) from each oyster. Using methods of Burge \& Friedman (2012) with some modifications, we targeted the OsHV-1 ORF 100/catalytic subunit of a DNA polymerase $\delta$ using the following forward (100 F: 5'-TGA TGG ATT GTT GGA CGA GA-3') and reverse (ORF 100R: 5'-ATC ACA TCC CTG GAC GCT AC-3') primers. A standard curve was generated from a dilution of a plasmid from 3 to $3 \times 10^{6}$ copies per reaction. Briefly, each $20 \mu \mathrm{l}$ reaction included $10 \mu \mathrm{l}$ of the Fast SYBR ${ }^{\mathrm{TM}}$ Green Master Mix, $15 \mu \mathrm{g}$ of BSA, $300 \mathrm{nM}$ of each primer, and $2 \mu \mathrm{l}$ of DNA ( $50 \mathrm{ng})$. The plasmid standard curve was run in triplicate, and samples in duplicate. All qPCR reactions used the Applied Biosystems 7500 Fast Real-time PCR system or Applied Biosystems QuantStudio 3 with a cut-off of 3 copies per reaction. qPCR runs were done with standards and random samples on both platforms to demonstrate consistency (data not shown). Cycling conditions for each qPCR run were $95^{\circ} \mathrm{C}$ for $20 \mathrm{~s}$ followed by 40 cycles of 95 and $60^{\circ} \mathrm{C}$. Following each run, a melting curve analysis was performed to confirm the specificity of each qPCR reaction by comparing the melting temperature peak of the positive control DNA to that of the experimental samples. The melting curve profile consisted of denaturation at $95^{\circ} \mathrm{C}$ for $15 \mathrm{~s}$ followed by an annealing step for $15 \mathrm{~s}$ at $60^{\circ} \mathrm{C}$. This was followed by continuous fluorescence monitoring during a $20 \mathrm{~min}$ temperature ramp to $95^{\circ} \mathrm{C}$ that was held for $15 \mathrm{~s}$. A limit of $\pm 1^{\circ} \mathrm{C}$ for melting temperature peak shift was set as the cutoff for species-specific amplifications.

\subsection{Data analysis}

All analyses were conducted in JMP 14.0 (SAS). Survivorship was analyzed with a Kaplan-Meier survival analysis using log-rank chi-squared statistics $(p<0.05)$. First, water type $\left(\mathrm{ASW}_{\text {Dist }}\right.$ vs. $\left.\mathrm{ASW}_{\text {Tap }}\right)$ was tested for each virus using all data; results indicated no difference in survival. Second, differences in survivorship were compared between AUS $\mu v a r$ and FRA $\mu$ var (pooling the water type). The qPCR data was $\log _{10}(x+1)$ transformed prior to analysis to normalize data. Least-squares regression was employed to determine differences in qPCR loads in tissues and tank water between AUS $\mu v a r$ and FRA $\mu v a r$ in each water type (overall data, $\mathrm{ASW}_{\text {Tap }}$ or $\mathrm{ASW}_{\text {Dist, }}$ and 
water type by day [Days 0-5 nested within water type]). Differences in tissue mean virus copies between survivors and dead oysters for each virus were tested using least-squares regression. Post hoc testing to identify differences between or among groups were conducted using a Tukey HSD for 3 or more factors.

\section{RESULTS}

Survival was low in oysters exposed to either OsHV-1 $\mu$ var and was significantly lower in those exposed to the AUS $\mu v a r(2.5 \%)$ than to the FRA $\mu$ var $(10 \%)(p=0.004, \log$-rank test statistic $=8.50, d f=1$, Fig. 1). The mean survival time was $3.58 \pm 0.17 \mathrm{~d}$ for oysters exposed to the AUS $\mu v a r$, and $4.33 \pm 0.23 \mathrm{~d}$ for oysters exposed to the FRA $\mu v a r$. All control oysters survived.

Tissue viral loads (Table 1) were similar between oysters exposed to AUS $\mu$ var and FRA $\mu v a r$ ( $p>0.05$; see Table 2 for tissue statistical outcomes). No differences in viral loads were detected between dead oysters or those that survived ( $p>0.05)$, although few survivors $(n=5)$ were available. In oysters exposed to the FRA $\mu v a r$, tissue levels differed among experimental days $(\mathrm{p}<0.001)$ with levels higher on Days 3 $\left(\mathrm{ASW}_{\text {Tap }}\right), 4\left(\mathrm{ASW}_{\text {Dist }}\right)$, and $5\left(\mathrm{ASW}_{\text {Dist }}\right)$ compared to Day $2\left(\mathrm{ASW}_{\text {Dist }}\right)(\mathrm{p}<0.05)$; viral loads from all other days and water types were similar to all others $(\mathrm{p}>$ 0.05). No differences in viral loads among days and water types were observed for oysters exposed to

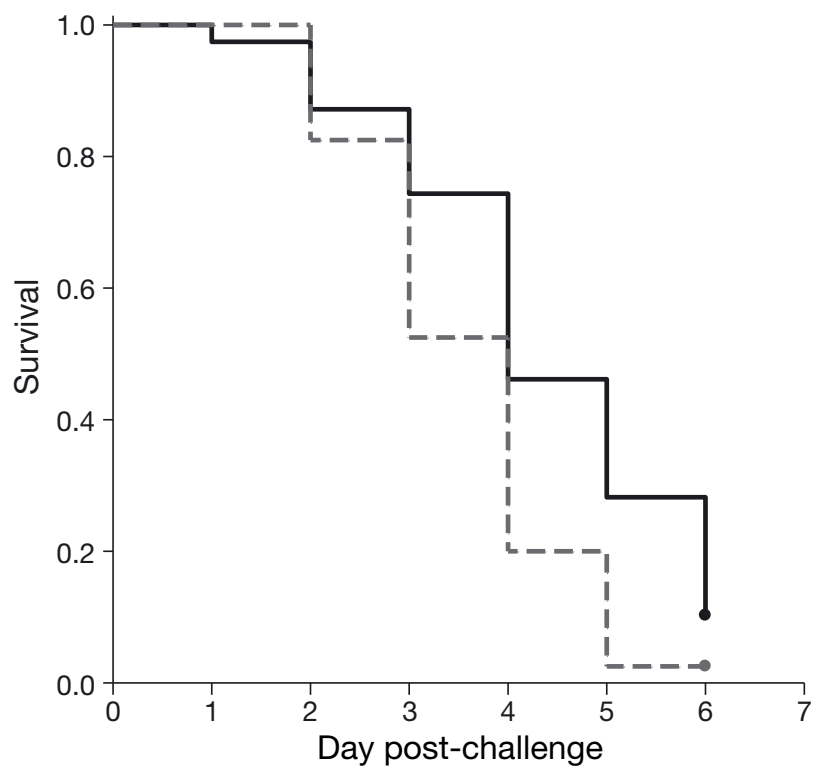

Fig. 1. Kaplan Meier survivorship curves for Crassostrea gigas seed exposed to OsHV-1 $\mu$ vars from France (solid line) and Australia (dashed line)
AUS $\mu$ var. When all days were pooled, no significant effect of water type on tissue loads was detected (i.e. $\mathrm{ASW}_{\text {Tap }}$ vs. $\mathrm{ASW}_{\text {Disti }} \mathrm{p}>0.05$ ) for either variant. No viral DNA was detected in control oysters.

The alkalinity of the $\mathrm{ASW}_{\text {Tap }}$ was $3782 \mu \mathrm{mol} \mathrm{kg}{ }^{-1}$ at 30 ppt vs. $2003 \mu \mathrm{mol} \mathrm{kg}{ }^{-1}$ ASW $_{\text {Dist. }}$. More AUS $\mu$ var DNA was detected in water from exposure tanks with $\mathrm{ASW}_{\text {Dist }}$ than in those with $\mathrm{ASW}_{\text {Tap }}(\mathrm{p}<0.05$; Table 3); water from exposure tanks with FRA $\mu$ var showed a similar but non-significant trend $(p=0.062)$ with the different seawaters. An increase in OsHV-1 $\mu$ var DNA was detected in tanks exposed to AUS uvar on Day $3(\mathrm{p}<0.01)$ but not in tanks exposed to FRA $\mu v a r$. Trace amounts of OsHV-1 $\mu$ var DNA were detected in water from the control tanks, but at significantly lower levels $(p=0.001)$.

PCR amplification produced a single band for each assay of the expected sizes for the C2/C6 ( 709 bp) and IA1/IA2 assays ( 607 bp) with the AUS $\mu v a r$ and the FRA uvar. Direct sequencing of the amplicons produced sequences of the same length (after trimming primer sequences) for AUS $\mu v a r$ and the FRA $\mu v a r$, i.e. $651 \mathrm{bp}(\mathrm{C} 2 / \mathrm{C} 6)$ and $576 \mathrm{bp}$ (IA1/IA2). Sequence alignments indicated a high degree of similarity between variants of $99.82 \%$ (IA1/IA2) and $100 \%$ (C2/C6) (Figs. S1 \& S2 in the Supplement at www.int-res.com/articles/suppl/d138p137_supp.pdf). Sequence data were deposited in GenBank under accession numbers MT157286-MT157289.

\section{DISCUSSION}

This is the first study to compare survival and infection of naive Pacific oysters from the West Coast of

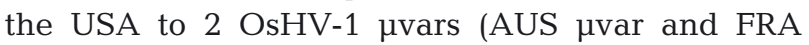
$\mu v a r)$, a first step in the much-needed characterization of the effects of the newly observed multiple variants of OsHV-1 in susceptible hosts. Overall survival of oysters was low (2.5-10\%), although trends varied statistically, and infection levels in tissues as measured by proxy using qPCR was high $\left(>10^{10}\right.$ mean copies $\mathrm{g}^{-1}$ ) and similar between OsHV-1 variants. Thus, the American oyster industry based on the Pacific oyster could be heavily impacted if OsHV-1 uvar from France or Australia is unintentionally introduced to the west coast of North America. Further experiments should be conducted using other oyster stocks to more fully characterize susceptibility or resistance of Pacific oyster stocks or specific family lines present in the USA (Divilov et al. 2019).

Mortality levels and high OsHV-1 copy number are consistent with highly susceptible stocks or family 
Table 1. OsHV-1 copy number for all samples collected in Crassostrea gigas tissue (copies g $^{-1}$ of tissue) or artificial seawater (copies $\mathrm{ml}^{-1}$ of seawater) made with either well water $\left(\mathrm{ASW}_{\text {Tap }}\right)$ or distilled water $\left(\mathrm{ASW}_{\text {Dist }}\right)$. SEM: standard error of mean

\begin{tabular}{|c|c|c|c|c|c|c|}
\hline Exposure & Sample type & Water & Os & $\begin{array}{c}1 \text { copies }- \\
\text { Mean }\end{array}$ & SEM & $\mathrm{N}$ \\
\hline Control & Tissue & $\mathrm{ASW}_{\text {Dist }}$ & $0.00-0.00$ & 0 & 0 & 19 \\
\hline Control & Tissue & $\mathrm{ASW}_{\mathrm{Tap}}$ & $0.00-0.00$ & 0 & 0 & 12 \\
\hline Control & Water & $\mathrm{ASW}_{\text {Dist }}$ & $(2.53-6.01) \times 10^{3}$ & $4.63 \times 10^{3}$ & $3.07 \times 10^{3}$ & 11 \\
\hline Control & Water & $\mathrm{ASW}_{\mathrm{Tap}}$ & $(1.33-5.15) \times 10^{3}$ & $3.09 \times 10^{3}$ & $3.69 \times 10^{2}$ & 11 \\
\hline AUS & Tissue & $\mathrm{ASW}_{\text {Dist }}$ & $(0.53-6.59) \times 10^{10}$ & $2.79 \times 10^{10}$ & $3.98 \times 10^{9}$ & 20 \\
\hline AUS & Tissue & $\mathrm{ASW}_{\mathrm{Tap}}$ & $(0.00-4.05) \times 10^{11}$ & $8.12 \times 10^{10}$ & $2.81 \times 10^{10}$ & 20 \\
\hline AUS & Water & $\mathrm{ASW}_{\text {Dist }}$ & $(0.05-4.22) \times 10^{5}$ & $1.65 \times 10^{5}$ & $4.39 \times 10^{4}$ & 10 \\
\hline AUS & Water & $\mathrm{ASW}_{\text {Tap }}$ & $(0.43-7.08) \times 10^{4}$ & $2.49 \times 10^{4}$ & $6.02 \times 10^{3}$ & 11 \\
\hline FRA & Tissue & $\mathrm{ASW}_{\text {Dist }}$ & $1.05 \times 10^{5}-1.07 \times 10^{11}$ & $3.60 \times 10^{10}$ & $7.78 \times 10^{10}$ & 20 \\
\hline FRA & Tissue & $\mathrm{ASW}_{\text {Tap }}$ & $1.04 \times 10^{5}-2.83 \times 10^{11}$ & $4.40 \times 10^{10}$ & $1.47 \times 10^{10}$ & 20 \\
\hline FRA & Water & $\mathrm{ASW}_{\text {Dist }}$ & $3.40 \times 10^{3}-3.21 \times 10^{5}$ & $6.75 \times 10^{4}$ & $2.79 \times 10^{4}$ & 14 \\
\hline FRA & Water & $\mathrm{ASW}_{\text {Tap }}$ & $1.01 \times 10^{3}-5.60 \times 10^{4}$ & $1.49 \times 10^{4}$ & $5.21 \times 10^{3}$ & 12 \\
\hline
\end{tabular}

Table 2. Variations in seed oyster tissue levels of OsHV-1 $\mu$ vars from Australia (AUS) and France (FRA) when held in seawater made with distilled water $\left(\mathrm{ASW}_{\text {Dist }}\right)$ or well water $\left(\mathrm{ASW}_{\mathrm{Tap}}\right)$. ns: not significant

\begin{tabular}{|c|c|c|c|c|c|c|c|c|c|c|}
\hline Virus & $\begin{array}{c}\text { Time } \\
\text { period }\end{array}$ & $\begin{array}{l}\text { Model effects } \\
\text { (fixed factors) }\end{array}$ & $\begin{array}{l}\text { ANOVA } \\
\text { Source }\end{array}$ & $\mathrm{df}$ & SS & MS & $F$-ratio & $\mathrm{p}$ & $\begin{array}{l}\text { Effect mag- } \\
\text { nitude: } \eta^{2}\end{array}$ & Outcome \\
\hline AUS & Overall & Water & $\begin{array}{c}\text { Model } \\
\text { Error } \\
\text { Total }\end{array}$ & $\begin{array}{c}1 \\
38 \\
39\end{array}$ & $\begin{array}{c}16.4 \\
662.1 \\
678.5\end{array}$ & $\begin{array}{c}16.4 \\
17.43\end{array}$ & 0.941 & $>0.05$ & $\mathrm{~ns}$ & No effect \\
\hline FRA & Overall & Water & $\begin{array}{l}\text { Model } \\
\text { Error } \\
\text { Total }\end{array}$ & $\begin{array}{c}1 \\
38 \\
39\end{array}$ & $\begin{array}{c}2.53 \\
883.9 \\
886.43\end{array}$ & $\begin{array}{c}2.53 \\
23.26\end{array}$ & 0.109 & $>0.05$ & ns & No effect \\
\hline AUS & Days 0-5 & Water/Day & $\begin{array}{l}\text { Model } \\
\text { Error } \\
\text { Total }\end{array}$ & $\begin{array}{c}8 \\
31 \\
39\end{array}$ & $\begin{array}{c}89.33 \\
589.12 \\
678.45\end{array}$ & $\begin{array}{c}11.17 \\
19\end{array}$ & 0.588 & $>0.05$ & ns & No effect \\
\hline FRA & Days 0-5 & $\begin{array}{l}\text { Water A } \\
\text { Day }\end{array}$ & $\begin{array}{c}\text { Model } \\
\text { Error } \\
\text { Total } \\
\text { ASW }_{\text {Tap }} \text { or ASW } \\
\text { Day }\end{array}$ & $\begin{array}{c}10 \\
29 \\
39 \\
1 \\
9\end{array}$ & $\begin{array}{c}525.88 \\
360.56 \\
886.43 \\
3.12 \\
523.35\end{array}$ & $\begin{array}{l}52.59 \\
12.43\end{array}$ & $\begin{array}{c}0.251 \\
4.68\end{array}$ & $\begin{array}{l}<0.01 \\
\\
>0.05 \\
<0.001\end{array}$ & $\begin{array}{cc}\mathrm{ns} & \\
1.00 & \\
& \text { Dó } \\
& \text { Day }\end{array}$ & 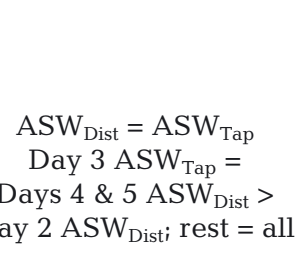 \\
\hline Both & Mortalities & Virus & $\begin{array}{l}\text { Model } \\
\text { Error } \\
\text { Total }\end{array}$ & $\begin{array}{c}1 \\
73 \\
74\end{array}$ & $\begin{array}{l}197.086 \\
1432.99 \\
1452.69\end{array}$ & $\begin{array}{l}197.086 \\
196.299\end{array}$ & 1.00 & $>0.05$ & ns & No effect \\
\hline
\end{tabular}

lines (Dégremont 2011, Oden et al. 2011, Hick et al. 2018). This study was terminated after $6 \mathrm{~d}$ when even the few survivors contained high tissue copy numbers $\left(1.85 \times 10^{6}\right.$ to $1.84 \times 10^{10}$ copies $\left.g^{-1} ; \mathrm{n}=5\right)$, suggesting that higher mortality might have occurred over subsequent days. Longer trials may be necessary to determine long-term survival potential and whether survivors represent resistant genotypes. No viral DNA was detected in control oysters, and to date, OsHV-1 has not been detected at the source nursery (C. A. Burge unpubl. data, R. Elston pers. comm). Low virus levels were observed in control water samples, likely as a result of aerosolization of viral DNA in the wet lab; no virus was amplified from control oyster tissues and no control oysters died.

Differential survival of Pacific oyster stocks and/or family lines to OsHV-1 variants has been well-documented in previous field and laboratory studies (reviewed by Dégremont et al. 2015). Further testing of oyster stocks and/or family lines with multiple $\mu v a r s$ is necessary to examine if resistance or susceptibility to one variant confers resistance to other variants. In France, oysters bred for high survival to 'summer mortality' and exposed to OsHV-1 were also 
Table 3. Variations in water levels of OsHV-1 $\mu$ vars from Australia (AUS) and France (FRA) when exposed Crassostrea gigas seed was held in seawater made with distilled water $\left(\mathrm{ASW}_{\text {Dist }}\right)$ or well water $\left(\mathrm{ASW}_{\text {Tap }}\right)$. ns: not significant

\begin{tabular}{|c|c|c|c|c|c|c|c|c|c|c|}
\hline Virus & $\begin{array}{l}\text { Time } \\
\text { period }\end{array}$ & $\begin{array}{l}\text { Model effects } \\
\text { (fixed factors) }\end{array}$ & $\begin{array}{l}\text { ANOVA } \\
\text { Source }\end{array}$ & $\mathrm{df}$ & SS & MS & $F$-ratio & $\mathrm{p}$ & $\begin{array}{r}\text { Effect mag } \\
\text { nitude: } \eta^{2}\end{array}$ & Outcome \\
\hline AUS & Overall & Water & $\begin{array}{c}\text { Model } \\
\text { Error } \\
\text { Total }\end{array}$ & $\begin{array}{c}1 \\
19 \\
20\end{array}$ & $\begin{array}{c}12.32 \\
31 \\
43.32\end{array}$ & $\begin{array}{c}12.32 \\
1.63\end{array}$ & 7.55 & $<0.05$ & 0.28 & $\mathrm{ASW}_{\text {Dist }}>\mathrm{ASW}_{\text {Tap }}$ \\
\hline FRA & Overall & Water & $\begin{array}{c}\text { Model } \\
\text { Error } \\
\text { Total }\end{array}$ & $\begin{array}{c}1 \\
24 \\
25\end{array}$ & $\begin{array}{c}8.81 \\
55.19 \\
64\end{array}$ & $\begin{array}{c}8.81 \\
2.3\end{array}$ & 3.83 & 0.062 & ns & $\begin{array}{c}\text { ns, but trend } \\
\text { for } \mathrm{ASW}_{\text {Dist }}>\mathrm{ASW}_{\text {Tap }}\end{array}$ \\
\hline AUS & Days 0-5 & Water/Day & $\begin{array}{c}\text { Model } \\
\text { Error } \\
\text { Total }\end{array}$ & $\begin{array}{c}9 \\
11 \\
20\end{array}$ & $\begin{array}{c}40 \\
3.32 \\
43.32\end{array}$ & $\begin{array}{c}4.44 \\
0.302\end{array}$ & 14.7 & $<0.0001$ & 0.92 & \\
\hline & & $\begin{array}{l}\text { Water A } \\
\text { Day }\end{array}$ & $\begin{array}{c}\mathrm{ASW}_{\text {Tap }} \text { or } \mathrm{ASW}_{\text {Dist }} \\
\text { Day }\end{array}$ & $\begin{array}{l}1 \\
8\end{array}$ & $\begin{array}{l}0.014 \\
27.68\end{array}$ & & $\begin{array}{l}0.048 \\
11.45\end{array}$ & $\begin{array}{l}>0.05 \\
<0.01\end{array}$ & $\begin{array}{c}\text { ns } \\
0.692 \quad I\end{array}$ & $\begin{array}{c}\mathrm{ASW}_{\text {Dist }}=\mathrm{ASW}_{\text {Tap }} \\
\text { Day } 3 \mathrm{ASW}_{\text {Dist }}>\text { rest }\end{array}$ \\
\hline FRA & Days 0-5 & Water/Day & $\begin{array}{c}\text { Model } \\
\text { Error } \\
\text { Total }\end{array}$ & $\begin{array}{l}11 \\
14 \\
25\end{array}$ & $\begin{array}{c}36.57 \\
27.43 \\
64\end{array}$ & $\begin{array}{l}3.32 \\
1.96\end{array}$ & 1.7 & $>0.05$ & ns & No effect \\
\hline
\end{tabular}

more resistant to OsHV-1 $\mu$ var (Dégremont 2011, Dégremont et al. 2015). In addition, resistant oysters were able to both limit infection loads and eliminate virus from their tissues (Dégremont 2011, Dégremont et al. 2015).

In challenge studies, water quality, such as alkalinity, may be an important consideration. In our study, more OsHV-1 $\mu$ var DNA was detected in tanks containing $\mathrm{ASW}_{\text {Dist, }}$ significantly so for the AUS $\mu v a r$ and a trend for FRA pvar. Thus, water quality (e.g. solutes) may be important for experimental challenges. The $\mathrm{ASW}_{\text {Tap }}$ at the UA APL has a high alkalinity so that when used to make artificial seawater, the total alkalinity was nearly double that made with $\mathrm{ASW}_{\text {Dist }}\left(\sim 1800 \mu \mathrm{mol} \mathrm{kg}{ }^{-1}\right.$ water higher). In the NE Pacific, ocean acidification (declining seawater $\mathrm{pH}$ and carbonate saturation) has been linked to oyster hatchery larval culture failures (Barton et al. 2012), with the industry responding by buffering the seawater with sodium carbonate to an alkalinity in excess of $3000 \mu \mathrm{mol} \mathrm{kg}{ }^{-1}$ seawater (Barton et al. 2015) similar to that used in our $\mathrm{ASW}_{\text {Tap }}$ treatment. Further testing of how seawater alkalinity influences the ability of OsHV-1 viruses to retain viability and transmissibility may provide useful information for hatcheries impacted by these viruses.

In the natural environment, the temperature necessary for OsHV-1 $\mu$ var outbreaks may be variable (Pernet et al. 2012, Jenkins et al. 2013, Paul-Pont et al. 2014, Renault et al. 2014, de Kantzow et al. 2016). Similar to many marine diseases (Burge et al. 2014), temperature is considered an important driver for OsHV-1 outbreaks and may be important in under- standing the relationship between OsHV-1 genotype and phenotype. For example, thermal thresholds for disease outbreaks are $16^{\circ} \mathrm{C}$ in France and $21^{\circ} \mathrm{C}$ in Australia (Pernet et al. 2012, Jenkins et al. 2013, Paul-Pont et al. 2014, Renault et al. 2014, de Kantzow et al. 2016). Importantly, differences in outbreak temperature thresholds may be related to several factors, including methods to measure, analyze, and report water temperatures, other co-varying environmental factors, and oyster physiological condition and/or genetics (de Kantzow et al. 2016). In our study, we maintained oysters at $22^{\circ} \mathrm{C}$, a similar temperature profile to studies showing disease transmission and high levels of mortality in experimental studies in France (Schikorski et al. 2011 a,b, Delisle et al. 2018) and Australia (Kirkland et al. 2015, de Kantzow et al. 2016), which may be an optimal temperature for full disease expression (de Kantzow et al. 2016, Delisle et al. 2018). However, to fully understand the oystervirus relationship, a next step is to test oyster susceptibility to these viruses across a thermal gradient. Thermal thresholds may differ among viruses and hosts and are important to identify in order to effectively manage these viruses. Additionally, recent studies have indicated that although OsHV-1 is necessary for initiating mortalities, opportunistic bacteria often colonize oysters infected with OsHV-1 (de Lorgeril et al. 2018); therefore, the role of both temperature and host microbiome, as well as the microbial environment, may be important factors to examine in future experiments.

In conclusion, we have provided the first comparison of the highly virulent French and Australian 
OsHV-1 $\mu$ vars. We suggest that many key questions remain to be answered in order to effectively manage OsHV-1 $\mu$ vars: What is an appropriate length of study to determine long-term survival potential of an oyster species, family line, or stock? How does water quality impact long-term viral viability, virulence, and transmissibility of OsHV-1? How might water temperature impact host susceptibility based on the thermal optima of both host and pathogen (i.e. virulence)? By answering these questions, we will enable aquaculturists and resource agencies to better manage our aquatic resources.

Acknowledgements. We thank Brenda Noble, Paul Schofield, and Tanner Padilla at the UA APL for laboratory space and technical support. We also thank Hog Island Oyster Company for providing oysters. N. Rivlin, R. Strenge, C. Robison, and G. Scott provided technical support. This research was funded in part by a grant from the National Aquaculture Initiative, National Oceanic and Atmospheric Administration, US Department of Commerce, under grant number NA14OAR4170078AM18; the School of Aquatic and Fishery Sciences, University of Washington; and Virginia Institute of Marine Sciences, William \& Mary. Additional funding to C.A.B. was provided through start-up funds to the Institute of Marine and Environmental Technology from the University of Maryland Baltimore County and the University of Maryland Baltimore. This is VIMS contribution no. 3883.

\section{LITERATURE CITED}

Abbadi M, Zamperin G, Gastaldelli M, Pascoli F and others (2018) Identification of a newly described OsHV-1 $\mu$ var from the North Adriatic Sea (Italy). J Gen Virol 99: 693-703

* Barbosa-Solomieu VB, Renault T, Travers MA (2015) Mass mortality in bivalves and the intricate case of the Pacific oyster, Crassostrea gigas. J Invertebr Pathol 131:2-10

Barton A, Hales B, Waldbusser GG, Langdon C, Feely RA (2012) The Pacific oyster, Crassostrea gigas, shows negative correlation to naturally elevated carbon dioxide levels: implications for near term ocean acidification effects. Limnol Oceanogr 57:698-710

Barton A, Waldbusser GG, Feely RA, Weisberg SB and others (2015) Impacts of coastal acidification on the Pacific Northwest shellfish industry and adaptation strategies implemented in response. Oceanography 28:146-159

* Burge CA, Friedman CS (2012) Quantifying Ostreid herpesvirus (OsHV-1) genome copies and expression during transmission. Microb Ecol 63:596-604

Burge CA, Eakin CM, Friedman CS, Froelich B and others (2014) Climate change influences on marine infectious disease: implications for management and society. Annu Rev Mar Sci 6:249-277

Burge CA, Shore-Maggio A, Rivlin ND (2018) Ecology of emerging infectious diseases of invertebrates. In: Hajek A, Shapiro D (eds) Ecology of invertebrate diseases. Wiley \& Sons, Hoboken, NJ, p 587-625
Carnegie RB, Arzul I, Bushek D (2016) Managing marine mollusk diseases in the context of regional and international commerce: policy issues and emerging concerns. Philos Trans R Soc B 371:20150215

* Davison AJ, Trus BL, Cheng NQ, Steven AC and others (2005) A novel class of herpesvirus with bivalve hosts. J Gen Virol 86:41-53

*Davison AJ, Eberle R, Ehlers B, Hayward GS and others (2009) The order Herpesvirales. Arch Virol 154: 171-177

de Kantzow M, Hick P, Becker JA, Whittington RJ (2016) Effect of water temperature on mortality of Pacific oysters Crassostrea gigas associated with microvariant ostreid herpesvirus 1 (OsHV-1 $\mu$ Var). Aquacult Environ Interact 8:419-428

De Lorgeril J, Lucasson A, Petton B, Toulza E and others (2018) Immune-suppression by OsHV-1 viral infection causes fatal bacteraemia in Pacific oysters. Nat Commun 9:4215

* Dégremont L (2011) Evidence of herpesvirus (OsHV-1) resistance in juvenile Crassostrea gigas selected for high resistance to the summer mortality phenomenon. Aquaculture 317:94-98

* Dégremont L, Garcia C, Allen SK Jr (2015) Genetic improvement for disease resistance in oysters: a review. J Invertebr Pathol 131:226-241

* Delisle L, Petton B, Burguin JF, Morga B, Corporeau C, Pernet $F$ (2018) Temperature modulate [sic] disease susceptibility of the Pacific oyster Crassostrea gigas and virulence of the Ostreid herpesvirus type 1. Fish Shellfish Immunol 80:71-79

* Divilov K, Schoolfield B, Morga B, Dégremont L and others (2019) First evaluation of resistance to both a California OsHV-1 variant and a French OsHV-1 microvariant in Pacific oysters. BMC Genet 20:96

FAO (2018) Fishery statistical collections: global aquaculture production (online query). Fisheries and Aquaculture Department, FAO, Rome. www.fao.org/fishery/ statistics/global-aquaculture-production/en

*Hick PM, Evans O, Rubio A, Dhand NK, Whittington RJ (2018) Both age and size influence susceptibility of Pacific oysters (Crassostrea gigas) to disease caused by Ostreid herpesvirus-1 (OsHV-1) in replicated field and laboratory experiments. Aquaculture 489:110-120

Jenkins C, Hick P, Gabor M, Spiers Z and others (2013) Identification and characterisation of an ostreid herpesvirus-1 microvariant (OsHV-1 $\mu$-var) in Crassostrea gigas (Pacific oysters) in Australia. Dis Aquat Org 105:109-126

Kirkland PD, Hick PM, Gu X (2015) Development of a laboratory model for infectious challenge of Pacific oysters (Crassostrea gigas) with ostreid herpesvirus type-1. Elizabeth Macarthur Agriculture Institute, Sydney

* Oden E, Martenot C, Berthaux M, Travaillé E, Malas JP, Houssin M (2011) Quantification of ostreid herpesvirus 1 (OsHV-1) in Crassostrea gigas by real-time PCR: determination of a viral load threshold to prevent summer mortalities. Aquaculture 317:27-31

OIE (2018) Infection with ostreid herpesvirus 1 microvariants. In: Manual of diagnostic tests for aquatic animals. www.oie.int/fileadmin/Home/eng/Health_standards/aa $\mathrm{hm} /$ current/chapitre_ostreid_herpesvirus_1.pdf

* Paul-Pont I, Evans O, Dhand NK, Rubio A, Coad P, Whittington RJ (2014) Descriptive epidemiology of mass mortality due to Ostreid herpesvirus-1 (OsHV-1) in commercially farmed Pacific oysters (Crassostrea gigas) in the Hawkes- 
bury River estuary, Australia. Aquaculture 422-423: 146-159

Pernet F, Barret J, Le Gall P, Corporeau C and others (2012) Mass mortalities of Pacific oysters Crassostrea gigas reflect infectious diseases and vary with farming practices in the Mediterranean Thau lagoon, France. Aquacult Environ Interact 2:215-237

Pernet F, Lupo C, Bacher C, Whittington RJ (2016) Infectious diseases in oyster aquaculture require a new integrated approach. Philos Trans R Soc B 371:20150213

Renault T, Arzul I (2001) Herpes-like virus infections in hatchery-reared bivalve larvae in Europe: specific viral DNA detection by PCR. J Fish Dis 24:161-167

Renault T, Bouquet AL, Maurice JT, Lupo C, Blachier P (2014) Ostreid herpesvirus 1 infection among Pacific oyster (Crassostrea gigas) spat: relevance of water temperature to virus replication and circulation prior to the onset of mortality. Appl Environ Microbiol 80:5419-5426

Editorial responsibility: Stephen Feist, Weymouth, UK
Schikorski D, Faury N, Pepin JF, Saulnier D, Tourbiez D, Renault T (2011a) Experimental ostreid herpesvirus 1 infection of the Pacific oyster Crassostrea gigas: kinetics of virus DNA detection by q-PCR in seawater and in oyster samples. Virus Res 155:28-34

Schikorski D, Renault T, Saulnier D, Faury N, Moreau P, Pepin JF (2011b) Experimental infection of Pacific oyster Crassostrea gigas spat by ostreid herpesvirus 1: demonstration of oyster spat susceptibility. Vet Res 42:27

Segarra A, Pepin JF, Arzul I, Morga B, Faury N, Renault T (2010) Detection and description of a particular Ostreid herpesvirus 1 genotype associated with massive mortality outbreaks of Pacific oysters, Crassostrea gigas in France in 2008. Virus Res 153:92-99

Wippel BJT (2017) Potential transgenerational effects of ocean acidification on the Olympia oyster, Ostrea lurida: a three-part experimental study. MSc thesis, University of Washington, Seattle, WA

Submitted: July 19, 2019; Accepted: January 21, 2020 Proofs received from author(s): March 3, 2020 